\title{
Increased tumour necrosis factor- $\alpha$ plasma levels during moderate-intensity exercise in COPD patients
}

\author{
R.A. Rabinovich*, M. Figueras ${ }^{\#}$, E. Ardite*, N. Carbó\# ${ }^{*}$ T. Troosters ${ }^{\Uparrow}$, X. Filella ${ }^{+}$, J.A. Barberà*, \\ J.C. Fernandez-Checa ${ }^{\S}$, J.M. Argilés ${ }^{\#}$, J. Roca*
}

Increased tumour necrosis factor- $\alpha$ plasma levels during moderate-intensity exercise in COPD patients. R.A. Rabinovich, M. Figueras, E. Ardite, N. Carbó, T. Troosters, X. Filella, J.A. Barberà, J.C. Fernandez-Checa, J.M. Argilés, J. Roca. (C)ERS Journals Ltd 2003.

ABSTRACT: Post-training downregulation of muscle tumour necrosis factor (TNF)- $\alpha$ messenger ribonucleic acid (mRNA) expression and decrease in cellular TNF- $\alpha$ levels have been reported in the elderly. It is hypothesised that chronic obstructive pulmonary disease (COPD) patients may not show these adaptations due to their reduced ability to increase muscle antioxidant capacity with training.

Eleven COPD patients (forced expiratory volume in one second $40 \pm 4.4 \%$ of the predicted value) and six age-matched controls were studied. Pre- and post-training levels of TNF- $\alpha$, soluble TNF receptors (sTNFRs: sTNFR55 and STNFR75) and interleukin (IL)-6 in plasma at rest and during exercise and vastus lateralis TNF- $\alpha$ mRNA were examined.

Moderate-intensity constant-work-rate exercise $(11 \mathrm{~min}$ at $40 \%$ of pretraining peak work-rate) increased pretraining plasma TNF- $\alpha$ levels in COPD patients (from 17 \pm 3.2 to $23 \pm 2.7 \mathrm{pg} \cdot \mathrm{mL}^{-1} ; \mathrm{p}<0.005$ ) but not in controls (from $19 \pm 4.6$ to $19 \pm 3.2 \mathrm{pg} \cdot \mathrm{mL}^{-1}$ ). No changes were observed in sTNFRs or IL-6 levels. After 8 weeks' endurance training, moderate-intensity exercise increased plasma TNF- $\alpha$ levels similarly to pretraining (from $16 \pm 3$ to $21 \pm 4 \mathrm{pg} \cdot \mathrm{mL}^{-1} ; \mathrm{p}<\mathbf{0 . 0 1}$ ). Pretraining muscle TNF- $\alpha$ mRNA expression was significantly higher in COPD patients than in controls (29.3 \pm 13.9 versus $5.0 \pm 1.5$ TNF-a/18S ribonucleic acid, respectively), but no changes were observed after exercise or training.

It is concluded that moderate-intensity exercise abnormally increases plasma tumour necrosis factor- $\alpha$ levels in chronic obstructive pulmonary disease patients without exercise-induced upregulation of the tumour necrosis factor- $\alpha$ gene in skeletal muscle. Eur Respir J 2003; 21: 789-794.
*Servei de Pneumologia (ICPCT), ${ }^{+}$Servicio de Bioquímica Clínica (Unitat d' Estudi del Càncer) and ${ }^{\S}$ Liver Unit (Institute of Digestive Diseases) and Higher Scientific Research Council, Hospital Clinic, Faculty of Medicine, August Pi i Sunyer Biomedical Research Institute, and ${ }^{\#}$ Dept of Biochemistry and Molecular Biology, Faculty of Biology, University of Barcelona, Barcelona, Spain. Faculty of Physical Education and Physiotherapy, Catholic University of Louvain, Louvain, Belgium.

Correspondence: J. Roca, Servei de Pneumologia, Hospital Clínic, Villarroel 170, Barcelona 08036, Spain.

Fax: 34932275455

E-mail: jroca@clinic.ub.es

Keywords: Chronic obstructive pulmonary disease, cytokines, exercise training, muscle redox capacity, skeletal muscle

Received: May 222002

Accepted after revision: December 202002

This study was supported by grants FIS 99/ 0029 and 00/0281 from the Spanish Fund for Health Research, e-Remedy (IST-2000-25146) from the European Union (FP5) and Comissionat per a Universitats i Recerca de la Generalitat de Catalunya (1999 SGR 00228). R.A. Rabinovich and $\mathrm{T}$. Troosters were research fellows supported by the European Respiratory Society (2000). M. Figueras is the recipient of a predoctoral scholarship from the Ministry of Education and Culture of the Spanish Government. Support was also received from E. Jaeger GmbH, Würzburg, Germany.
Different lines of evidence involve cytokines, particularly tumour necrosis factor (TNF)- $\alpha$, in the process of skeletal muscle wasting observed in $\sim 20 \%$ of chronic obstructive pulmonary disease (COPD) patients [1-5]. Muscle redox status itself and activation of transcription factors, such as nuclear factor- $\kappa \mathrm{B}$, by reactive oxygen species $[6,7]$, seem to be involved in the signal transduction pathways that modulate cellular TNF- $\alpha$ levels. Moreover, it has been reported that exercise training in normal elderly humans downregulates TNF- $\alpha$ messenger ribonucleic acid (mRNA) expression and decreases muscle TNF- $\alpha$ levels [8], probably related to enhancement of the oxygen transport/utilisation system.

It is well accepted that heavy exercise induces abnormally high levels of oxidative stress in COPD patients [9]. It was recently shown that, after 8 weeks' endurance training at the same relative load, muscle redox potential appears to be reduced in COPD patients, but not in age-matched healthy sedentary controls [10].
In the present study, it was hypothesised that COPD patients may exhibit an abnormal cytokine response to exercise. They might not show training downregulation of muscle TNF- $\alpha$, as reported in healthy subjects [8], because of their lower antioxidant capacity after training [10]. This study examines the effects of both endurance training and moderateintensity exercise (before and after training) on: 1) plasma cytokine (TNF- $\alpha$, soluble TNF receptors (sTNFRs: sTNFR55 and sTNFR75) and interleukin (IL)-6) levels; and 2) TNF- $\alpha$ mRNA expression in limb skeletal muscle, in a group of 11 patients with COPD and six age-matched healthy controls [10].

\section{Methods}

\section{Study group}

According to American Thoracic Society criteria [11] examined in the study of RABINOVICH et al. [10], 11 of the 
17 COPD patients and six healthy sedentary age- and sexmatched controls were included in the study. All participants signed the written informed consent form approved by the Committee on Investigations involving Human Subjects at the Hospital Clinic, University of Barcelona, Barcelona, Spain.

\section{Study design}

Selection procedures for inclusion in the study and details of the design have been reported previously [10]. Briefly, preand post-training measurements were made to assess the effects of endurance training (incremental exercise testing, phosphorus-31 magnetic resonance spectroscopy and kinetics of pulmonary oxygen uptake $\left(V^{\prime} \mathrm{O}_{2}\right)$ ) (not reported in the present study) and evaluate changes in plasma cytokine levels during constant-work-rate exercise.

All subjects trained for 5 days $^{-w_{e}} \mathrm{k}^{-1}$ for 8 weeks. Training sessions were of 60 min duration and split into small blocks of 2-5 min of high-intensity continuous cycling ( $\sim 60$ revolutions per minute (rpm) at $\sim 90 \%$ of the peak work-rate ( $W$ peak) at the end of the training programme) for an effective period of $\geqslant 30 \mathrm{~min}$. The recovery time between the high-intensity periods consisted of cycling at the same speed and at $<60 \%$ of pretraining $W$ peak. The first week was used as an adaptation period, during which the high-intensity blocks were initially of $60 \%$ of $W$ peak. Subsequently, the work level was raised until values close to the $90 \%$ of pretraining $W$ peak were reached and maintained until the end of the training period.

\section{Constant-work-rate exercise}

After an arterial catheter (Seldicath; Plastimed, Saint Leu la Forêt, France) was placed, subjects were installed on the cycle ergometer with the mouthpiece in place, which allowed online calculation of $V^{\prime} \mathrm{O}_{2}$. They cycled for $11 \mathrm{~min}$ at a constant work-rate of $40 \%$ of pretraining $W$ peak at a speed of $60 \mathrm{rpm}$. The rationale for choosing a moderate-intensity constantwork-rate protocol was to devise a sustainable exercise activity [12]. Arterial blood sampling for measurements of plasma cytokine levels was performed at rest, after $11 \mathrm{~min}$ of steady-state exercise and $20 \mathrm{~min}$ after exercise.

\section{Muscle biopsy}

After appropriate antisepsis and anaesthesia of the skin, a muscle biopsy sample was obtained in a subset of nine COPD patients and the six healthy controls from the vastus lateralis muscle using a Bergström needle (Unimed S.A., Lausanne, Switzerland). Muscle samples were immediately frozen in liquid nitrogen and stored at $-70^{\circ} \mathrm{C}$ until analysis.

\section{Cytokine measurements}

Plasma tumour necrosis factor- $\alpha$, soluble tumour necrosis factor receptor and interleukin-6 levels. Plasma levels of TNF- $\alpha$, sTNFRs (sTNFR55 and sTNFR75) and IL-6 were assessed by enzyme-linked immunosorbent assay (BioSource Europe, Nivelles, Belgium for IL-6 and TNF- $\alpha$; Bender MedSystems, Vienna, Austria for sTNFRs) [13] and results were expressed in picograms per millilitre. Intra-assay coefficients of variation at different TNF- $\alpha$ concentrations $(86.7 \pm 4.4$, $591 \pm 22$ and $1,027 \pm 15 \mathrm{pg} \cdot \mathrm{mL}^{-1} ; \mathrm{n}=20$ ) were $5.1,3.7$ and $1.4 \%$, respectively. Interassay coefficients of variation at different
TNF- $\alpha$ concentrations $\left(41 \pm 4,162 \pm 13\right.$ and $664 \pm 66 \mathrm{pg} \cdot \mathrm{mL}^{-1}$; $\mathrm{n}=10,13$ and 10 , respectively) were $9.7,8.0$ and $9.9 \%$, respectively. The minimum detectable concentration was estimated to be $3 \mathrm{pg} \cdot \mathrm{mL}^{-1}$ (Biosource Europe, Nivelles, Belgium).

Skeletal muscle tumour necrosis factor- $\alpha$ messenger ribonucleic acid expression. Total vastus lateralis muscle ribonucleic acid (RNA) was extracted using the TriPure ${ }^{\mathrm{TM}}$ kit (BoehringerMannheim, Mannheim, Germany), a commercial modification of the acid guanidinium isothiocyanate/phenol/chloroform method described by CHOMCZYNSKI and SACCHI [14]. TNF- $\alpha$ mRNA was measured using a two-step reverse transcriptase (RT) polymerase chain reaction (PCR) method [15] using appropriate forward (5'-AAGAGTTCCCCAGGGACCTCT-3') and reverse (5'-CCTGGGAGTAGATGAGGTACA-3') primers (Gene Specific Relative RT-PCR kit; Ambion, Inc., Austin, TX, USA). The predicted size of the amplified product using these primers is 233 base pairs (bp). Briefly, for each sample, $5 \mu \mathrm{g}$ RNA were reversetranscribed to give the complementary deoxyribonucleic acid in the presence of appropriate antisense primers. The PCR was carried out as follows: one cycle of $1 \mathrm{~min}$ at $94^{\circ} \mathrm{C} ; 33$ cycles of $1 \mathrm{~min}$ at $94^{\circ} \mathrm{C}, 1 \mathrm{~min}$ at $61^{\circ} \mathrm{C}$ and $2 \mathrm{~min}$ at $72^{\circ} \mathrm{C}$; and 1 cycle of $4 \mathrm{~min}$ at $72^{\circ} \mathrm{C}$, in the presence of $1.5 \mathrm{mM} \mathrm{MgCl}_{2}$. All reactions were standardised at 33 cycles to ensure that the samples were assayed within the exponential phase of the PCR. The RT-PCR products were electrophoresed in $2 \%$ agarose gels in tris-(hydroxymethyl)-aminomethane (Tris)/borate/ethylenediamine tetraacetic acid (EDTA) buffer $(\mathrm{pH} \mathrm{8.0)}$. The gel was stained with ethidium bromide and bands quantified by scanning densitometry. TNF- $\alpha$ mRNA expression was expressed relative to $18 \mathrm{~S}$ RNA expression. The set of primers used amplify a segment of the $18 \mathrm{~S}$ ribosomal RNA (rRNA) with a predicted size of $495 \mathrm{bp}$. The abundance of rRNA is a major limitation to its utility as a control, since an endogenous control must be present within the same linear concentration range as the RNA under study when amplified under the same conditions. Ambion's Competimer $^{\text {TM }}$ technology (Quantum RNA 18 S; Ambion, Inc., patent pending) allows attenuation of the amplification of $18 \mathrm{~S}$ rRNA by using a modified primer (competimer) that cannot be extended. In this way, the expression of the internal control can be modulated to the level of even rare messages without affecting the performance of other targets in a multiplex PCR. The proportion of primer:competimer used was 3:17.

\section{Data analysis}

Data are expressed as mean \pm SEM. Changes within groups were analysed using a paired t-test. Comparisons between groups were performed using an unpaired t-test. When normality tests failed, a logarithmic transformation was applied to the data. A p-value of $<0.05$ was taken as significant.

\section{Results}

The COPD group (age 65 \pm 1.4 yrs (range 59-72 yrs); body mass index (BMI) $25 \pm 1.5 \mathrm{~kg} \cdot \mathrm{m}^{-2}\left(\right.$ range $\left.15-36 \mathrm{~kg} \cdot \mathrm{m}^{-2}\right)$ ) encompassed a broad spectrum of disease severity (table 1). These patients showed a severe obstructive ventilatory defect (forced expiratory volume in one second (FEV1) $40 \pm 4.4 \%$ of the predicted value (range $15-57 \%$ pred); arterial oxygen tension $9.2 \pm 0.44 \mathrm{kPa}(69 \pm 3.3 \mathrm{mmHg})$ (range $7.2-11.8 \mathrm{kPa}$ (54-89 mmHg))) with limited exercise tolerance (peak $V^{\prime} \mathrm{O}_{2}$ $\left(V^{\prime} \mathrm{O}_{2}\right.$, peak) $17 \pm 1.6 \mathrm{~mL} \cdot \mathrm{kg}^{-1} \cdot \mathrm{min}^{-1}\left(\right.$ range $\left.9-27 \mathrm{~mL} \cdot \mathrm{kg}^{-1} \cdot \mathrm{min}^{-1}\right)$ ). Healthy sedentary controls were matched by sex (all male), age $(63 \pm 1.9 \mathrm{yrs})$ and BMI $\left(27 \pm 0.9 \mathrm{~kg} \cdot \mathrm{m}^{-2}\right)$ and showed normal pulmonary function (FEV1 $112 \pm 11 \%$ pred) and exercise tolerance $\left(V^{\prime} \mathrm{O}_{2}\right.$, peak $\left.24 \pm 0.8 \mathrm{~mL} \cdot \mathrm{kg}^{-1} \cdot \mathrm{min}^{-1}\right)$. As reported in 
Table 1.-Characteristics of the study group

\begin{tabular}{lcc}
\hline & COPD & Control \\
\hline Age yrs & $65 \pm 1.4$ & $63 \pm 1.9$ \\
Weight kg & $66.0 \pm 4.1$ & $75.7 \pm 1.6^{*}$ \\
$\mathrm{BMI} \mathrm{kg} \cdot \mathrm{m}^{-2}$ & $24.7 \pm 1.5$ & $26.9 \pm 0.9$ \\
FEV1 L & $1.13 \pm 0.1$ & $3.5 \pm 0.3^{* * *}$ \\
$\%$ pred & $40 \pm 4.4$ & $112 \pm 10.6^{* * *}$ \\
FVC \% pred & $59 \pm 3.5$ & $108 \pm 6.5^{* * *}$ \\
FEV1/FVC & $0.45 \pm 0.03$ & $0.80 \pm 0.06^{* * *}$ \\
TLC \% pred & $94 \pm 4.6$ & $99 \pm 7.0$ \\
FRC \% pred & $126 \pm 10.9$ & $96 \pm 5.3^{* *}$ \\
RV/TLC & $0.6 \pm 0.03$ & $0.32 \pm 0.03^{* * *}$ \\
$P \mathrm{a}, \mathrm{O}_{2} \mathrm{mmHg}$ & $69 \pm 3.3$ & $100 \pm 3.3^{* * *}$ \\
$P \mathrm{a}, \mathrm{CO}_{2} \mathrm{mmHg}$ & $42 \pm 1.6$ & $36 \pm 1.3^{* *}$ \\
\hline
\end{tabular}

Data are presented as mean \pm SEM. COPD: chronic obstructive pulmonary disease; BMI: body mass index; FEV1: forced expiratory volume in one second; \% pred: percentage of the predicted value; FVC: forced vital capacity; TLC: total lung capacity; FRC: functional residual capacity; RV: residual volume; $\mathrm{Pa}, \mathrm{O}_{2}$ and $\mathrm{Pa}_{\mathrm{a}}, \mathrm{CO}_{2}$ : arterial oxygen and carbon dioxide tension, respectively, both measured breathing room air. *: $\mathrm{p}<0.05 ; * *: \mathrm{p}<0.01 ; * * *: \mathrm{p}<0.001$ (unpaired-t test); $(1 \mathrm{mmHg}=$ $0.133 \mathrm{kPa}$.$) .$
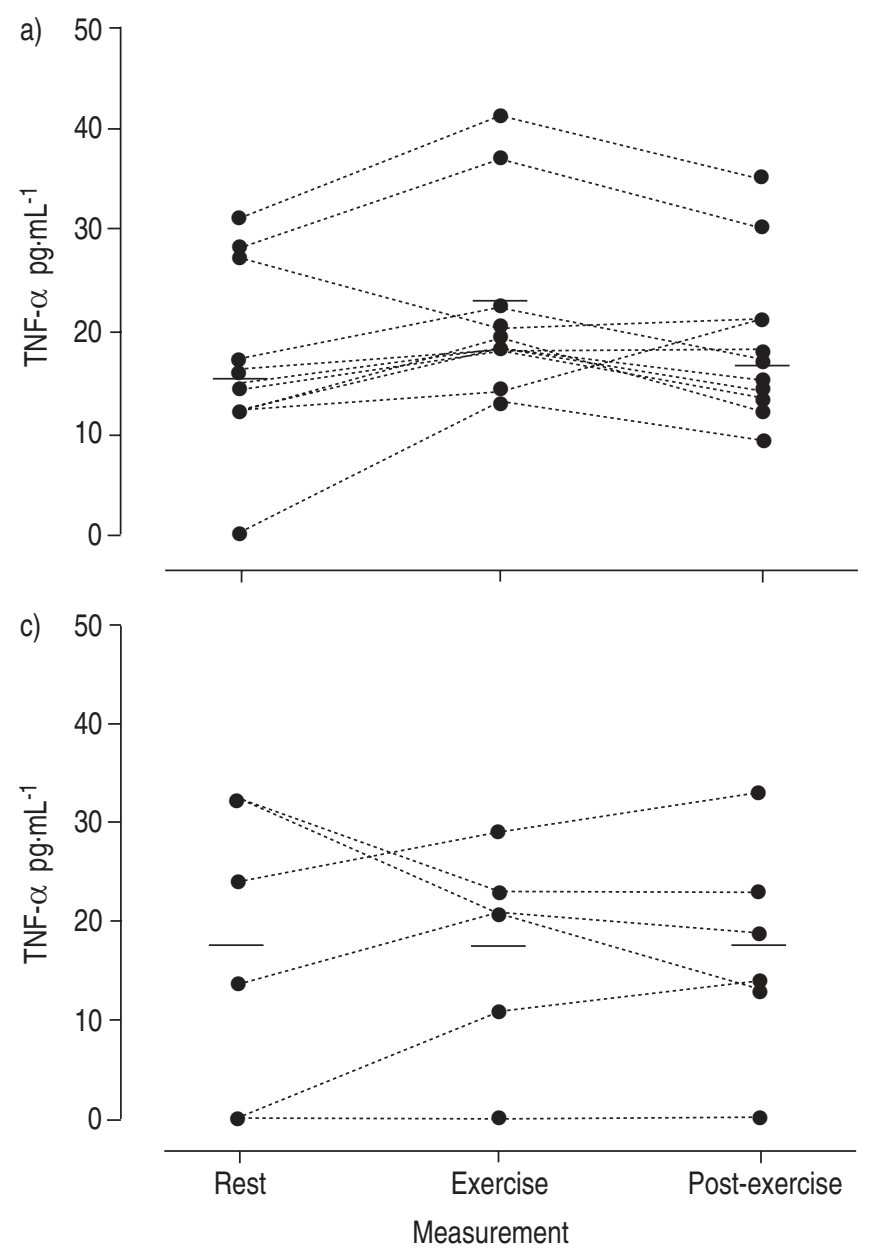

detail in RABINOVICH et al. [10], a significant training effect was observed in the two groups. In COPD patients, exercise tolerance increased ( $W$ peak $41 \pm 12 \% ; V^{\prime} \mathrm{O}_{2}$, peak $10.5 \pm 3 \%$; both $\mathrm{p}<0.01)$ and arterial lactic acid concentration at the same work-rate fell by $20 \pm 6 \%$ after training $(\mathrm{p}<0.01)$. Likewise, healthy sedentary controls showed enhanced exercise tolerance ( $W$ peak $32 \pm 13 \%, \mathrm{p}=0.05 ; V^{\prime} \mathrm{O}_{2}$, peak $14 \pm 3 \%, \mathrm{p}<0.005$ ) and arterial lactic acid concentration at the same work-rate fell by $12.5 \pm 3.9 \%$ after training $(\mathrm{p}<0.05)$.

\section{Plasma cytokine levels during exercise and after training}

No differences in plasma TNF- $\alpha$ levels at rest were observed between patients and controls $\left(17 \pm 3.2\right.$ and $19 \pm 4.6 \mathrm{pg} \cdot \mathrm{mL}^{-1}$, respectively). It is worth noting, however, that COPD patients showed significantly increased plasma TNF- $\alpha$ levels during moderate-intensity constant-work-rate exercise (from 17 \pm 3.2 to $23 \pm 2.7 \mathrm{pg} \cdot \mathrm{mL}^{-1}, \mathrm{p}<0.005$ ); this was not seen in the control group. It should be noted that all subjects reach a plateau in $V^{\prime} \mathrm{O}_{2}$ at this workload. Plasma TNF- $\alpha$ levels showed a trend towards returning to resting values $20 \mathrm{~min}$ after exercise (fig. 1a). Exercise training did not modify the exercise-induced response to plasma TNF- $\alpha$ levels seen in the COPD group (fig. 1b).

b)

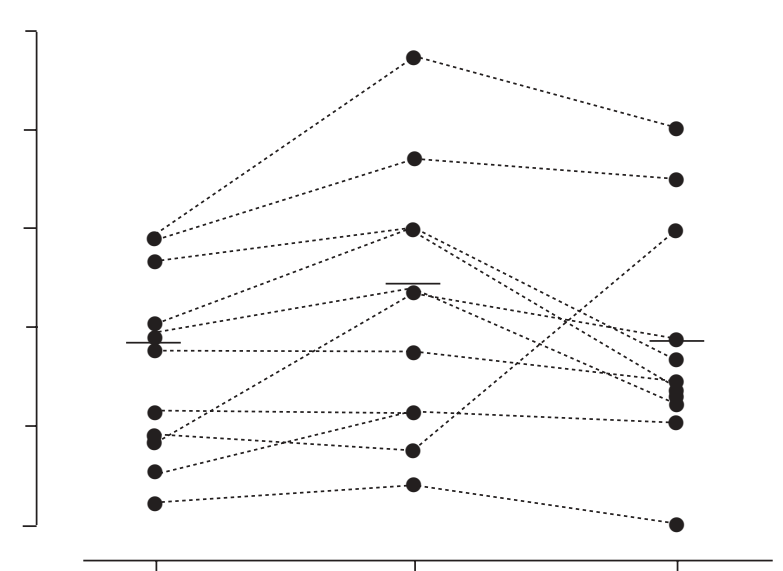

d)

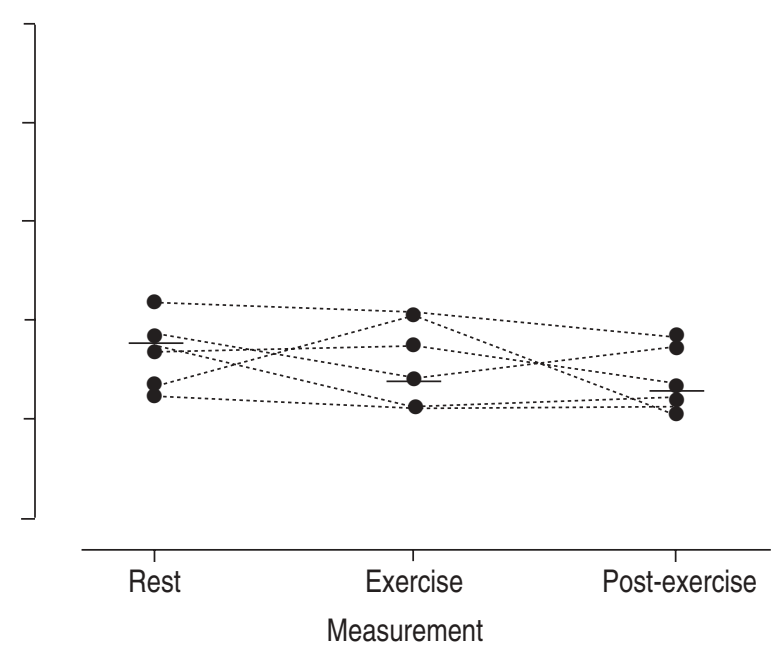

Fig. 1. - Individual plasma tumour necrosis factor (TNF)- $\alpha$ levels before (a and c) and after (b and d) training in chronic obstructive pulmonary disease patients $(\mathrm{a}$ and $\mathrm{b})(\mathrm{p}<0.005$ and $\mathrm{p}<0.01$, exercise versus rest, respectively) and control subjects (c and $\mathrm{d})$ (both $\mathrm{p}=$ nonsignificant). Levels of TNF- $\alpha$ were measured at rest, after 11 min of moderate-intensity constant-work-rate exercise at $40 \%$ of pretraining peak work-rate, and 20 min after exercise. Horizontal bars represent means. 
a)
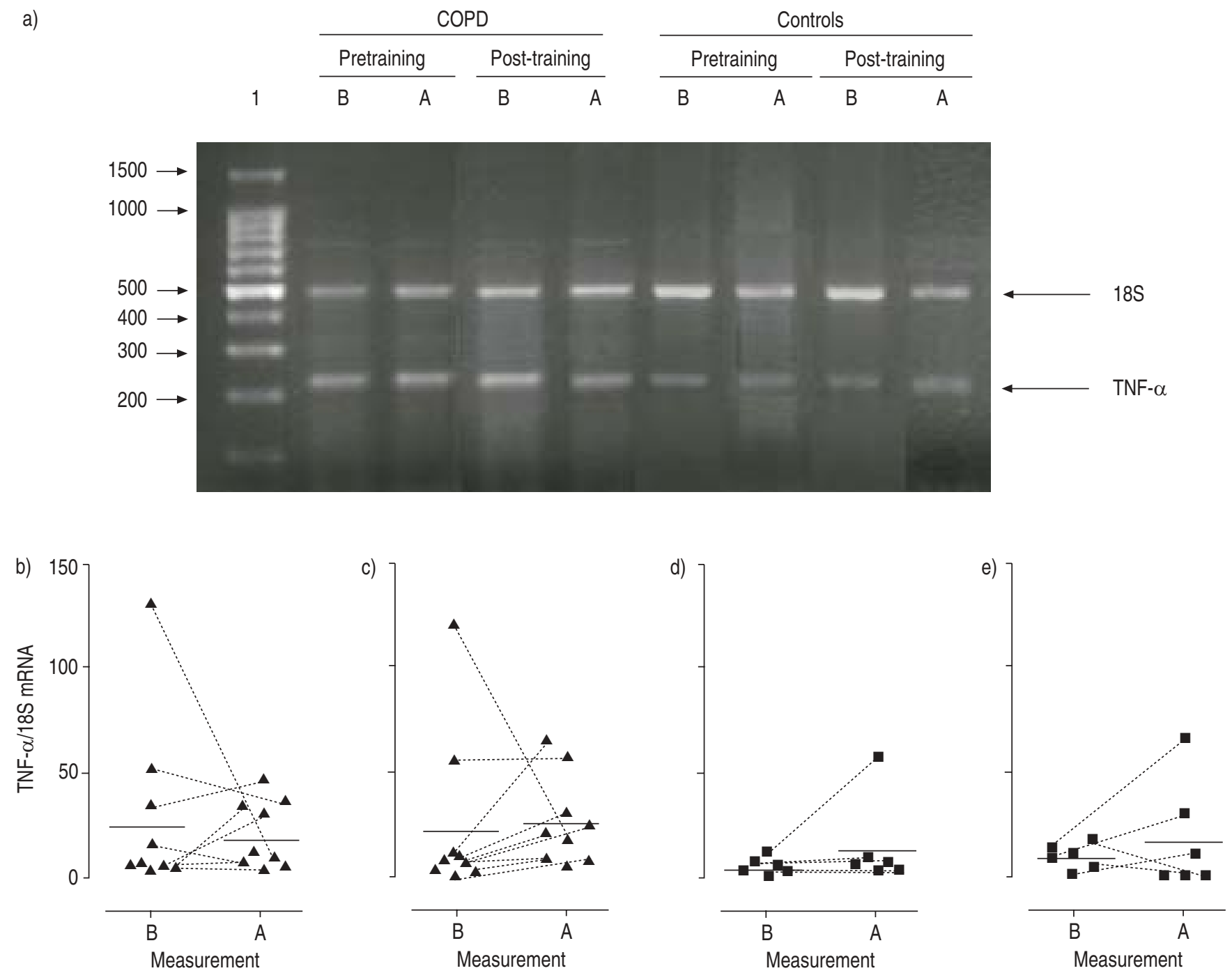

Fig. 2. -a) Representative reverse transcriptase polymerase chain reaction for tumour necrosis factor (TNF)- $\alpha$ messenger ribonucleic acid (mRNA) (233 base pairs (bp)) and 18S mRNA (488 bp) ribosomal subunit expression in vastus lateralis muscle (lane 1: ribonucleic acid ladder). b) Individual TNF- $\alpha / 18 \mathrm{~S}$ mRNA expression in chronic obstructive pulmonary disease (COPD) patients (b and c) and healthy controls (d and e) before $(b$ and $d)$ and after ( $c$ and e) training, before $(B)$ and after $(A)$ constant-work-rate exercise at $40 \%$ of pretraining peak work-rate. Horizontal bars represent means. $\mathrm{p}<0.05$ versus healthy controls.

Pretraining plasma levels of sTNFRs at rest were similar between COPD patients $\left(0.19 \pm 0.04\right.$ and $0.69 \pm 0.12 \mathrm{pg} \cdot \mathrm{mL}^{-1}$ sTNFR 55 and sTNFR 75, respectively) and controls $(0.40 \pm 0.10$ and $0.90 \pm 0.28 \mathrm{pg} \cdot \mathrm{mL}^{-1}$, respectively). Likewise, no differences between the two groups were seen in plasma IL-6 levels at rest $\left(7.9 \pm 2.4\right.$ and $6.1 \pm 3.8 \mathrm{pg} \cdot \mathrm{mL}^{-1}$ in COPD and controls, respectively). No changes in sTNFR or IL-6 level were observed during moderate-intensity exercise or after training in the two groups (data not shown).

\section{Skeletal muscle tumour necrosis factor- $\alpha$ messenger ribonucleic acid expression}

At rest, TNF- $\alpha$ mRNA expression was significantly higher in COPD patients $(29.3 \pm 13.9 \mathrm{TNF}-\alpha / 18 \mathrm{~S})$ than in healthy sedentary subjects $(5.0 \pm 1.5 \mathrm{TNF}-\alpha / 18 \mathrm{~S})(\mathrm{p}<0.05)$, showing marked heteroscedascity in the COPD group, as shown in figure 2. No significant changes in muscle TNF- $\alpha$ mRNA expression after moderate-intensity exercise (fall of $8.3 \pm 14.7$ TNF- $\alpha / 18 \mathrm{~S}$ ) or endurance training (increase of $5.4 \pm 8.3 \mathrm{TNF}-$ $\alpha / 18 S$ ) were seen in COPD patients. Similarly, healthy sedentary controls did not show changes in muscle TNF- $\alpha$ mRNA expression after exercise (increase of $9.0 \pm 9.2 \mathrm{TNF}-\alpha / 18 \mathrm{~S}$ ) or training (increase of $3 \pm 15.8 \mathrm{TNF}-\alpha / 18 \mathrm{~S}$ ).

Taking into account only those patients who underwent muscle biopsy, no correlation was found between muscle TNF- $\alpha$ mRNA expression and plasma TNF- $\alpha$ levels. It is worth noting that no difference was observed between this subgroup and the whole group in plasma TNF- $\alpha$ level $(19 \pm 1.7$ and $17 \pm 3.2 \mathrm{pg} \cdot \mathrm{mL}^{-1}$, respectively).

\section{Discussion}

\section{Increase in plasma tumour necrosis factor- $\alpha$ levels}

The main finding of the present study was a consistent rise in plasma TNF- $\alpha$ levels (before and after training) after 11 min of moderate-intensity constant-work-rate cycling exercise in COPD patients (figs $1 \mathrm{a}$ and $\mathrm{b}$ ); this was not observed in healthy sedentary controls (figs $1 \mathrm{c}$ and $\mathrm{d}$ ). This phenomenon was not accompanied by changes in levels of sTNFRs or IL-6. 
To the present authors' knowledge, this study reports for the first time the greater sensitivity of COPD patients to showing increases in plasma cytokine levels at moderate-intensity sustainable exercise. Interestingly, normal subjects and trained athletes at high exercise levels show increased plasma IL-6 levels as the predominant exercise-induced cytokine.

Baseline plasma TNF- $\alpha$ (and sTNFR) levels were generally within the reference limits of the authors' laboratory $\left(<20 \mathrm{pg} \cdot \mathrm{mL}^{-1}\right)$ [16]. Since the COPD group generally showed normal BMIs, no differences in level between patients and controls were expected at rest $\left(17 \pm 3.2\right.$ versus $19 \pm 4.6 \mathrm{pg} \cdot \mathrm{mL}^{-1}$ for patients and controls, respectively). Unfortunately body composition was not assessed in the present study and analysis by fat-free mass could not be performed [17].

It should be noted that, even after 8 weeks of exercise training, moderate exercise gave rise to increased levels of plasma TNF- $\alpha$; this was not seen in the control group. In healthy subjects [18], it is well established that both strenuous and long-term endurance exercise increase levels of circulating pro-inflammatory cytokines, particularly IL-6. Although the sources of cytokine release during strenuous exercise remain controversial, different potential origins for increased secretion of these mediators have been suggested, the first of which is regarded as most likely: 1) intensively working muscles [19]; 2) sympathetic activation acting on immune organs [18]; 3) fat tissue [20]; and 4) blood mononuclear cells [21, 22]. The latter, however, is a controversial issue [23, 24]. Increased IL-6 mRNA expression has been detected in lower limb muscle biopsy samples after marathon running, coinciding with the rise in circulating IL-6 levels [19]. Cytokine plasma levels seem to be related to two main factors: 1) intensity and duration of exercise; and 2) muscle damage induced by high-intensity exercise. The level of exercise performed by the present study group was moderate and perfectly sustainable as assessed by steady-state conditions of cardiac frequency and $V^{\prime} \mathrm{O}_{2}$. Thus, none of the conditions linked to strenuous exercise occurred in the present study.

It is well accepted that skeletal muscle TNF- $\alpha$ may have autocrine and/or paracrine physiological functions, and its role in metabolic regulation is well known. It has been suggested that TNF- $\alpha$ may decrease fat mass by stimulating lipolysis [25] and increasing plasma leptin levels [26]. Signal transduction pathways sensitive to reactive oxygen species $[7,27]$ seem to play a fundamental role in modulating cellular levels of this cytokine [8]. In the present patients, however, moderate levels of exercise did not provoke detectable changes in muscle redox status, as reported in detail by RABINOVICH et al. [10]. Likewise, no exercise-induced change in TNF- $\alpha$ mRNA expression was seen in the COPD group. In the present study, TNF- $\alpha$ mRNA expression was analysed by RT-PCR. A single product of the expected size was amplified. Although not sequenced, this most likely corresponds to the predicted segment of TNF- $\alpha$, based upon its electrophoretic mobility.

Since the second muscle biopsy sample was taken immediately after exercise, the time elapsed seems to be insufficient for de novo synthesis of muscle TNF- $\alpha$ [28]. Similarly, COLBERT et al. [29] found plasma IL-6 levels to be increased in mice after intense exercise without any change in mRNA expression in lung, liver, brain or skeletal muscle. In agreement with the present findings, these authors did not find increased muscle TNF- $\alpha$ mRNA expression after exercise. Nevertheless, it can be speculated that exercise could have triggered the release of preformed TNF- $\alpha$ from muscle via post-transcriptional regulation mechanisms. Enhanced levels of reactive oxygen species [10] may induce cytokine release at a post-transcriptional level, independent of RNA synthesis [30]. Although the regulation of TNF- $\alpha$ was characterised at the molecular level by determining vastus lateralis TNF- $\alpha$ mRNA expression, the lack of measurement of corresponding cellular protein levels, due to the limited availability of muscle samples, limits interpretation of some of the findings.

\section{Lack of training effects on muscle tumour necrosis factor- $\alpha$ messenger ribonucleic acid expression}

Upregulation of muscle TNF- $\alpha$ mRNA expression (fig. 2) was observed in three (BMI 20.6, 20.1 and $26.1 \mathrm{~kg} \cdot \mathrm{m}^{-2}$, respectively) of nine (33\%) COPD patients during the pretraining measurements at rest. These three patients did not show abnormal resting plasma TNF- $\alpha$ levels or differences in exercise or training effects compared to the rest of the subjects. In the present study, no relationships were found between plasma TNF- $\alpha$ levels and BMI or TNF- $\alpha$ mRNA expression.

The COPD group did not show training-induced downregulation of TNF- $\alpha$ mRNA expression. This kind of result was expected because of the lower muscle antioxidant capacity after high-intensity physical training in these patients compared to healthy controls [10]. It is well known that reactive oxygen species induce dose-dependent release of cytokines [31]. Moreover, administration of antioxidant has been demonstrated to downregulate the release of cytokines secondarily to exercise [23]. The present authors acknowledge, however, that the lack of measurements of muscle TNF- $\alpha$ levels do not allow clear-cut conclusions in this regard.

The concomitant absence of training-induced downregulation of muscle TNF- $\alpha$ mRNA expression in the control group should also be mentioned, and could be partly attributable to the different type of training programme employed in the current study compared to the study of GREIWE et al. [8]. It is worth noting that the aforementioned study was conducted in frail elderly subjects (aged $81 \pm 1$ yrs) who underwent a 3-month light stretching exercise pretraining programme followed by a supervised resistance exercise training programme ( 3 days $\cdot$ week $^{-1}$ ) for an additional period of 3 months. In summary, both the duration of training and muscle groups exercised were different from those in the present study.

It is concluded that patients with chronic obstructive pulmonary disease show an abnormal increase in circulating plasma tumour necrosis factor- $\alpha$ levels during moderateintensity exercise, not accompanied by the increase in interleukin-6 levels usually seen in healthy subjects during strenuous exercise, concomitant with an absence of traininginduced effects on muscle tumour necrosis factor- $\alpha$ messenger ribonucleic acid expression. The present authors consider that their results pose significant questions, particularly those related to the abnormal tumour necrosis factor- $\alpha$ response during moderate exercise and its relationship to the systemic effects of the disease. Further research is needed to clarify the origin and physiological significance of these findings.

Acknowledgements. The authors are grateful to F. Burgos, C. Gistau and J.L. Valera and all the technical staff of the Lung Function Laboratory (Hospital Clinic, August Pi i Sunyer Biomedical Research Institute, Barcelona, Spain) for their skilful support during the study. J. Vilaró, A. Capitán, C. Gonzalez and E. Vilar of the Blanquerna University School of Nursing and Physiotherapy (Barcelona, Spain) are acknowledged for their outstanding work in conducting the training sessions. The authors acknowledge C. Hernandez, coordinator nurse of the Home Care Unit (Hospital Clinic, August Pi i Sunyer Biomedical Research Institute), for help in patient recruitment. The authors would especially like to thank R. Bastos (Hospital Clinic, 
August Pi i Sunyer Biomedical Research Institute) for valuable help in the revision of this manuscript. P.D. Wagner (Division of Physiology, University of California, San Diego, CA, USA) is acknowledged for careful and critical reading of the manuscript.

\section{References}

1. Takabatake $\mathrm{M}$, Nakamura $\mathrm{H}$, Abe $\mathrm{S}$, et al. Circulating leptin in patients with chronic obstructive pulmonary disease. Am J Respir Crit Care Med 1999; 159: 1215-1219.

2. Di Francia M, Barbier D, Mege J, Orehek J. Tumor necrosis factor-alpha and weight loss in chronic obstructive pulmonary disease. Am J Respir Crit Care Med 1994; 150: 14531455.

3. de Godoy I, Donahoe M, Calhoun WJ, Mancino J, Rogers RM. Elevated TNF- $\alpha$ production by peripheral blood monocytes of weight-losing COPD patients. Am J Respir Crit Care Med 1996; 153: 633-637.

4. Creutzberg EC, Schols AMWJ, Weling-Scheepers CAPM, Buurman WAW, Wouters EF. Characterization of nonresponse to high caloric oral nutritional therapy in depleted patients with chronic obstructive pulmonary disease. $\mathrm{Am} \mathrm{J}$ Respir Crit Care Med 2000; 161: 745-752.

5. Takabatake $\mathrm{M}$, Nakamura $\mathrm{H}$, Abe $\mathrm{H}$, et al. The relationship between chronic hypoxemia and activation of the tumor necrosis factor- $\alpha$ system in patients with chronic obstructive pulmonary disease. Am J Respir Crit Care Med 2000; 161: $1179-1184$.

6. Li YP, Schwartz RJ, Waddell IA, Holloway BR, Reid MB. Skeletal muscle myocytes undergo protein loss and reactive oxygen-mediated NF- $\kappa \mathrm{B}$ activation in response to TNF- $\alpha$. FASEB J 1998; 12: 871-880.

7. Chandel NS, Trzyna WX, McClintock DS, Schumacker PT. Role of oxidants in NF-kappa B activation and TNF-alpha gene transcription induced by hypoxia and endotoxin. J Immunol 2000; 165: 1013-1021.

8. Greiwe JS, Cheng B, Rubin DC, Yarasheski KE, Semenkovich CF. Resistance exercise decreases skeletal muscle tumor necrosis factor $\alpha$ in frail elderly humans. FASEB J 2001; 15: 475-482.

9. Viña J, Servera E, Asensi M, et al. Exercise causes blood glutathione oxidation in chronic obstructive pulmonary disease: prevention by $\mathrm{O}_{2}$ therapy. J Appl Physiol 1996; 81 : 2199-2202.

10. Rabinovich RA, Ardite E, Troosters T, et al. Reduced muscle redox capacity after endurance training in COPD patients. Am J Respir Crit Care Med 2001; 164: 1114 1118 .

11. ATS. Standards for the diagnosis and care of patients with chronic obstructive pulmonary disease. Am J Respir Crit Care Med 1995; 152: Suppl. 4, S77-S121.

12. Sala E, Roca J, Marrades RM, et al. Effects of endurance training on skeletal muscle bioenergetics in chronic obstructive pulmonary disease. Am J Respir Crit Care Med 1999; 159: $1726-1734$.

13. Beutler B, Cerami A. Cachectin: more than a tumor necrosis factor. $N$ Engl J Med 1987; 316: 379-385.

14. Chomczynski P, Sacchi N. Single-step method of RNA isolation by acid guanidinium thiocyanate-phenol-chloroform extraction. Anal Biochem 1987; 162: 156-159.

15. Ardite E, Sans M, Panes J, Romero FJ, Pique JM, Fernandez Checa JC. Replenishment of glutathione levels improves mucosal function in experimental acute colitis. Lab Invest 2000; 80: 734-744

16. Kreuzer KA, Rockstroh JK, Sauerbruch T, Spengler U A comparative study of different enzyme immunosorbent assays for human tumor necrosis factor-alpha. $J$ Immunol Methods 1996; 195: 49-54.

17. Eid AA, Ionescu AA, Nixon LS, et al. Inflammatory response and body composition in chronic obstructive pulmonary disease. Am J Respir Crit Care Med 2001; 164 1414-1418.

18. Drenth JP, Van Uum SH, Van Deuren M, Pesman GJ, Van der Ven-Jongekrijg J, Van der Meer JW. Endurance run increases circulating IL-6 and IL-1ra but downregulates ex vivo TNF-alpha and IL-1 beta production. J Appl Physiol 1995; 79: 1497-1503.

19. Ostrowski K, Schjerling P, Pedersen BK. Physical activity and plasma interleukin-6 in humans - effect of intensity of exercise. Eur J Appl Physiol 2000; 83: 512-515.

20. Nara M, Kanda $\mathrm{T}$, Tsukui $\mathrm{S}$, et al. Running exercise increases tumor necrosis factor-alpha secreting from mesenteric fat in insulin-resistant rats. Life Sci 1999; 65: 237-244.

21. Rhind SG, Castellani JW, Brenner IK, et al. Intracellular monocyte and serum cytokine expression is modulated by exhausting exercise and cold exposure. Am J Physiol Regul Integr Comp Physiol 2001; 281: R66-R75.

22. Rivier A, Pene J, Chanez P, et al. Release of cytokines by blood monocytes during strenuous exercise. Int J Sports Med 1994; 15: 192-198.

23. Vassilakopoulos T, Katsaounou P, Karatza MH, Kollintza A, Zakynthinos S, Roussos C. Strenuous resistive breathing induces plasma cytokines: role of antioxidants and monocytes. Am J Respir Crit Care Med 2002; 166: 1572-1578.

24. Moldoveanu AI, Shephard RJ, Shek PN. Exercise elevates plasma levels but not gene expression of IL-1beta, IL-6, and TNF-alpha in blood mononuclear cells. J Appl Physiol 2000; 89: 1499-1504.

25. Hauner H, Petruschke T, Russ M, Rohrig K, Eckel J. Effects of tumour necrosis factor alpha (TNF alpha) on glucose transport and lipid metabolism of newly-differentiated human fat cells in cell culture. Diabetologia 1995; 38: 764 771 .

26. Grunfeld C, Zhao C, Fuller J, et al. Endotoxin and cytokines induce expression of leptin, the ob gene product, in hamsters. J Clin Invest 1996; 97: 2152-2157.

27. Vassilakopoulos T, Zakynthinos S, Roussos C. Strenuous resistive breathing induces proinflammatory cytokines and stimulates the HPA axis in humans. Am J Physiol 1999; 277: R1013-R1019.

28. Albarenque SM, Suzuki K, Nakayama H, Doi K. Kinetics of cytokines mRNAs expression in the dorsal skin of WBN/ILA-Ht rats following topical application of T-2 toxin. Exp Toxicol Pathol 2001; 53: 271-274.

29. Colbert LH, Davis JM, Essig DA, Ghaffar A, Mayer EP. Tissue expression and plasma concentrations of TNF alpha, IL-1beta, and IL-6 following treadmill exercise in mice. Int $J$ Sports Med 2001; 22: 261-267.

30. Yoshida Y, Maruyama M, Fujita T, et al. Reactive oxygen intermediates stimulate interleukin-6 production in human bronchial epithelial cells. Am J Physiol 1999; 276: L900L908.

31. Haddad JJ, Safieh-Garabedian B, Saade NE, Kanaan SA, Land SC. Chemioxyexcitation (delta pO2/ROS)-dependent release of IL-1 beta, IL-6 and TNF-alpha: evidence of cytokines as oxygen-sensitive mediators in the alveolar epithelium. Cytokine 2001; 13: 138-147. 